\title{
Isolation and Characterization of Lactic Acid Bacteria From Milk and Their Effects on the Pathogenic Bacteria
}

\author{
Ciamak Ghazaei ${ }^{1}$ (D) \\ 1. Department of Microbiology, University of Mohaghegh Ardabili, Ardabil, Iran.
}

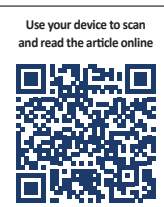

Citation Ghazaei C. Isolation and Characterization of Lactic Acid Bacteria From Milk and Their Effects on the Pathogenic Bacteria . Research in Molecular Medicine. 2020; 8(4):189-200. https://doi.org/10.32598/rmm.8.4.4

doi https://doi.org/10.32598/rmm.8.4.4

Article info:

Received: 12 Aug 2020

Revised: 20 Sep 2020

Accepted: 14 Oct 2020

Keywords:

Lactic acid bacteria (LAB), Lactobacillus/Lactobacilli, Probiotics, Antimicrobial activities, Milk

\begin{abstract}
A B S T RA C T
Background: Probiotics are "live microbial cells" that are beneficial for human and animal health. Lactobacilli are such a diverse group of bacteria with similarmetabolic and physiological characteristics, and constitute important and beneficial gut microflora. During carbohydrate fermentation, lactobacilli produce lactic acid as an end product in metabolism. Hence, lactobacilli have high significance to be used as probiotics in the food industry, because of their acidifying properties. Also, lactobacilli are considered "safe", owing to their ubiquitous presence in the food. Many researchers provided evidence for the presence of lactobacilli in milk sources. Thus, the present study aimed to isolate and characterize different lactobacilli strains from milk sources and analyze their "probiotic potential".

Materials and Methods: Forty-one lactobacilli isolates were obtained from raw cow milk. Then, the strains were characterized by morphological identification and biochemical tests. Besides, probiotic potentials were evaluated with the bile tolerance test, antibiotic susceptibility test, and determining suitable $\mathrm{pH}$ for the optimal growth of lactobacilli. The lactobacilli isolates were also analyzed for their probiotic characteristics and the release of antimicrobial substances. Their antimicrobial activities against pathogenic strains were assessed by determining the minimum inhibitory concentration, with the help of agar diffusion methods.

Results: From 50 milk samples, 41 lactobacilli isolates were obtained, out of which five lactobacilli strains were identified as Lactobacillus casei, Lactobacillus plantarum, Lactobacillus brevis, Lactobacillus acidophilus, and Lactobacillus lactis. Moreover, 35 isolates showed an inhibitory effect. These strains were able to survive and grow in $0.5 \%$ to $2.5 \%$ bile salt concentrations. Lactic acid bacteria were susceptible to antibiotics, and 35 isolates obtained from raw milk showed an inhibitory effect against pathogenic bacteria. The observed minimum inhibitory concentration ranged from 50 to $100 \mu \mathrm{L}$ and varied between the different pathogens.

Conclusion: Out of 41 Lactobacillus isolates obtained from cow milk samples, 35 were identified with probiotic characteristics. Hence, this study highlighted the novel probiotic bacteria and validated the antimicrobial properties of the Lactobacillus spp against pathogenic bacteria.
\end{abstract}

\footnotetext{
* Corresponding Author:

Ciamak Ghazaei, PhD.

Address: -Department of Microbiology, University of Mohaghegh Ardabili, Ardabil, Iran.

Phone: +98 (45) 33512081

E-mail: ciamakghazaei@yahoo.com
} 


\section{Introduction}

or thousands of years, antibiotics have been used against pathogenic bacteria [1] but the ubiquitous use of antibiotics F has led to antibiotic resistance in various bacteria. Consequently, researchers have to find substitute treatments to cure bacterial diseases [2-4]; probiotics are the most convincing alternatives.

According to the Food and Agriculture Organization/ World Health Organization, probiotics are "living microorganisms that, when administered in adequate amounts, confer health benefits on the host" [5, pp5]. Probiotics improve the gut bacteria balance of their host. To classify a microorganism as a probiotic, several criteria are implemented: the probiotic bacteria should survive in the upper gastrointestinal (GI) tract and overcome gastric acidity; should be functionally active in the gut environment; should have the capability to adhere to the intestinal mucosa; and should be non-pathogenic, viable, and active, during food production and storage [6-10]. The most common among probiotics are lactobacilli that are a group of miscellaneous bacteria and have prevalent metabolic and physiological characteristics. The rarely motile, gram-positive, non-spore-forming Lactobacillus is one of the major Lactic Acid Bacteria (LAB) genera used as probiotics. They have known health benefits and are ubiquitously present in food $[11,12]$. The health characteristics of lactobacilli include immune modulation, which can reduce the symptoms of lactose intolerance and relief from inflammatory bowel disease $[6,11]$. Some strains of lactobacilli, such as $L$. acidophilus, $L$. casei, $L$. paracasei, and $L$. rhamnosus are increasingly being used in novel dairy products to improve the food quality and human health [13].

In lactobacilli strains, carbohydrate metabolism/fermentation produces lactic acid as a major end product that helps to inhibit the pathogenic bacteria proliferation. Acidification inhibits the growth of these spoilage agents and provides an additional hurdle for the pathogenic microorganisms. Bacteria like $S$. Typhimurium, $S$. dysenteriae, E. coli, B. cereus, and H. pylori cause many food poisoning cases [13-17]. Probiotic bacteria differ in the level of antagonism against specific pathogenic bacteria. Hence, it is indispensable to regulate dairy products and find novel probiotics with efficient antagonistic properties against pathogenic bacteria [11]. Since milk is a primary dairy product, this study aimed to evaluate numerous milk samples to isolate and characterize different Lactobacillus strains and analyze their probiotic potentials against pathogenic bacteria.

\section{Materials and Methods}

\section{Collection of samples}

Lactobacilli: Fifty different raw cow milk samples were collected, next, $10 \mathrm{~mL}$ of each sample was added to $90 \mathrm{~mL}$ of $0.86 \%$ sterile normal saline solution to make suspensions. Then, they were enriched in deMan Rogosa Sharpe (MRS) broth (HiMedia, India) and spread on the plate of MRS agar medium (HiMedia, India), which were later incubated at the temperature of $37^{\circ} \mathrm{C}$ for $21 \pm 3$ h. Thus, lactobacilli from milk samples were cultured and isolated in modified MRS broth and MRS agar medium, respectively [18]. Also, the selection of Lactobacillus was improved using $0.05 \%$ cysteine (Padtan Teb Co.), which was added into the MRS medium and the $\mathrm{pH}$ was adjusted to $6.5 \pm 0.2$ [19].

Pathogenic bacteria: Salmonella Typhimurium ATCC 1596, Shigella dysenteriae ATCC 1188, E. coli ATCC 10799, and Bacillus cereus ATCC 1252 were collected from Iran Science and Technology Research Organization. Also, Helicobacter pylori was provided from the Central Pathobiology Laboratory of the Hospital. Then, the pathogenic bacterial strains of Salmonella Typhimurium, Escherichia coli, and Shigella dysenteriae were cultured in the aerobic condition in brain heart infusion agar, at the temperature of $37^{\circ} \mathrm{C}$. Also, Helicobacter pylori was incubated under microaerophilic conditions.

Isolation of the acid and bile resistant strains of Lactobacillus

The milk samples were screened for 3-6 $\mathrm{h}$ in phosphate buffer saline, at a pH of 3.0 and 6.0 to isolate acid and bile-resistant bacteria. A volume of $100 \mu \mathrm{L}$ of freshly grown bacteria was added into the environment of the liquid MRS containing $0.3 \%, 0.7 \%$, and $1 \%$ sterile bile salts. Next, the growth of bacteria was recorded at times $0,2,4$, and $8 \mathrm{~h}$; the growth was examined by recording absorption reading at a wavelength of $600 \mathrm{~nm}$. Later, the grown lactobacilli under such conditions were isolated using the MRS medium. Each sample was homogenized with a sterile phosphate solution, at the temperature of $35 \pm 5^{\circ} \mathrm{C}$ and the speed of 200 to $400 \mathrm{rpm}$ in a Stomacher. Then, $1 \mathrm{~mL}$ of each diluted sample was inoculated in the tube-containing MRS medium, under aseptic conditions. Also, a distilled water sample was used with each batch of samples as the control. The incubation of the MRS broth inoculated tubes was done, at the temperature of $37^{\circ} \mathrm{C}$, for $24-48 \mathrm{~h}$. The MRS medium and agar culture were tested for various parameters, such as temperature, $\mathrm{pH}$, anaerobic conditions, and incubation periods, which 
can affect the bacterial growth [6]. Then, the tubes were observed, and the isolation of lactobacilli strains was carried out, based on the morphology of the colonies. Next, the strains were subcultured on the MRS medium containing Petri dishes and incubated at the temperature of $37^{\circ} \mathrm{C}$ for $48 \mathrm{~h}$.

\section{Characterization and identification of LAB strains}

The isolated bacteria were identified as Lactobacillus spp, according to Bergey's manual [20]. The Gram staining technique and cell morphological tests were used to identify the morphology of the bacteria and isolates, respectively [6]. Besides, additional biochemical tests included catalase and oxidase tests and carbohydrate fermentation and milk coagulation [6]. Thus, the Lactobacillus isolates were confirmed, then, the isolates were stored in the MRS broth containing $10 \%$ skim milk and $30 \%$ glycerol, at the temperature of $-20{ }^{\circ} \mathrm{C}$. Finally, the species of isolated Lactobacillus was determined by comparing them with the reference Lactobacillus spp.

\section{Probiotic characterization}

\section{Determination of $\mathrm{pH}$ for optimal growth}

Modifying the $\mathrm{pH}$, the optimal growth of Lactobacillus spp was determined. The isolated single colony was subcultured in the MRS broth, and $1 \%(\mathrm{v} / \mathrm{v})$ of this solution was inoculated in the MRS broth of different $\mathrm{pH}$ (range, 2.0-8.0). Accordingly, the $\mathrm{pH}$ was adjusted with $1 \mathrm{M}$ solutions of $\mathrm{NaOH}$ or $\mathrm{HCl}$. They were incubated at the temperature of $37^{\circ} \mathrm{C}$ for $24 \mathrm{~h}$. Subsequently, the bacterial growth potential was measured, using a spectrophotometer (UpLab, Italy), in which the optical density was observed at $600 \mathrm{~nm}[13,21]$.

\section{Tolerance test for bile salts}

According to the modified method of Gilliland et al., a bile salt tolerance test was carried out to assess the bile salt tolerance ability of the potential probiotics [22]. The bacterial strains were incubated into five MRS medium tubes with the bile salt concentrations of $0.5 \%, 1 \%$, $1.5 \%, 2 \%$, and $2.5 \%$ (Purified Ox Bile Salts), at the temperature of $37^{\circ} \mathrm{C}$, for $24 \mathrm{~h}$. Also, a bile salt-free MRS medium inoculated with the lactobacilli strains was used as control. Then, the absorbance at $600 \mathrm{~nm}$ was measured for the observed bacterial growth.

\section{Antibiotic susceptibility test}

The disk diffusion method was used to evaluate the antibiotic susceptibility of the isolated lactobacilli strains.
The method was designed, according to ISO (International Organization for Standardization) standards and the quality assurance guidelines of the World Health Organization [23]. The cultures were swabbed on MuellerHinton agar plates, also, antibiotics were used in the form of blank discs (HiMedia, India). The applied antibiotics were as follows: ampicillin $(10 \mu \mathrm{g})$, amoxiclav $(5 \mu \mathrm{g})$, cloxacillin $(5 \mu \mathrm{g})$, azithromycin $(15 \mu \mathrm{g})$, cefotaxime (30 $\mu \mathrm{g})$, cefixime $(30 \mu \mathrm{g})$, clindamycin $(5 \mu \mathrm{g})$, cotrimoxazole $(25 \mu \mathrm{g})$, chloramphenicol $(30 \mu \mathrm{g})$, ciprofloxacin $(5 \mu \mathrm{g})$, ceftriaxone $(30 \mu \mathrm{g})$, erythromycin $(15 \mu \mathrm{g})$, gentamicin $(10 \mu \mathrm{g})$, tetracycline $(30 \mu \mathrm{g})$, novobiocin $(5 \mu \mathrm{g})$, and oxacillin $(5 \mu \mathrm{g})$. Also, the reference strains of $L$ acidophilus ATCC 314 and L plantarum ATCC 13643 were used for the quality control, in antibiotic susceptibility tests. All the plates were incubated at the temperature of $37^{\circ} \mathrm{C}$, for $24 \mathrm{~h}$, then, the zones of inhibition were measured.

\section{Antimicrobial activity}

The antagonistic activity of each bacterial strain against the pathogenic bacteria was determined using the agar well diffusion method [24, 25]. Initially, the lactobacilli were cultured in microaerophilic conditions, then, 25 $\mathrm{mL}$ of the culture fluid was centrifuged for 10 minutes at the speed of $4000 \mathrm{rpm}$, and the supernatant was passed through a $0.22 \mu \mathrm{m}$ filter. About $50 \mu \mathrm{l}$ of the cell-free supernatant of each characterized Lactobacillus spp was used to fill the $7 \mathrm{~mm}$ diameter well in nutrient agar containing pathogenic bacteria. The pathogens used for the test included S. Typhimurium, S. dysenteriae, E. coli, B. cereus, and $H$. pylori. These plates were incubated at the temperature of $37^{\circ} \mathrm{C}$, for $24 \mathrm{~h}$, then, the diameter of clear zones of inhibition was measured.

\section{Characterization of antimicrobial substances}

The agar well diffusion technique was used to assess the antimicrobial substance production of the isolated LAB strains, which included L. casei, L. plantarum, $L$. brevis, L. acidophilus, and L. lactis [26, 27]. A volume of $25 \mathrm{~mL}$ of the MRS broth was used to grow the bacterial strains at the temperature of $37^{\circ} \mathrm{C}$, for an overnight. Then, the strains were centrifuged at $\times 4000 \mathrm{~g}$, for 10 minutes, at the temperature of $4^{\circ} \mathrm{C}$. Also, the supernatant liquid of each strain was divided into equal portions of 5 $\mathrm{mL}$, where one portion was used for various assays. The samples were processed as follows:

- Bacteriocin assay: The supernatant liquid was treated with $1 \mathrm{mg} / \mathrm{mL}$ pronase or $1 \mathrm{mg} / \mathrm{mL}$ trypsin, then, 0.22 $\mu \mathrm{m}$ pore size filters (Axiva Sichem Pvt. Ltd.) were used for filtering. 
Table 1. Morphological characteristics of the five observed lactobacillus strains

\begin{tabular}{ccccc}
\hline Lactobacillus Strains & No. of Colonies & Gram Staining & Spore Formation & Motility \\
\hline L. casei & 15 & Gram+ve, bacilli & Non-spore & Non-motile \\
\hline L. plantarum & 6 & Gram+ve, bacilli & Non-spore & Non-motile \\
\hline L. brevis & 6 & Gram+ve, bacilli & Non-spore & Non-motile \\
\hline L. acidophilus & 5 & Gram+ve, bacilli & Non-spore & Non-motile \\
\hline L. lactis & 3 & Gram+ve, bacilli & Non-spore & Non-motile \\
\hline
\end{tabular}

Table 2. Biochemical characteristics of the five observed lactobacillus strains

\begin{tabular}{ccccc}
\hline Lactobacillus Strains & Catalase Test & Oxidase Test & Carbohydrate Fermentation Test & Milk Coagulation \\
\hline L. casei & - & - & + & + \\
L. plantarum & - & - & + & + \\
L. brevis & - & - & + & + \\
L. acidophilus & - & - & + & + \\
\hline L. lactis & - & - & + & + \\
\hline
\end{tabular}

- Organic acids assay: The supernatant liquid was adjusted to the $\mathrm{pH}$ of $6.5 \pm 0.1$ with the help of $\mathrm{NaOH}$.

- Hydrogen peroxide assay: The supernatant liquid was treated with $0.5 \mathrm{mg} / \mathrm{mL}$ of catalase.

First, the $7 \mathrm{~mm}$ diameter wells were filled with 50 to $100 \mu \mathrm{L}$ of each supernatant and seeded with a $1 \%(\mathrm{v} / \mathrm{v})$ culture of each test pathogen, at the temperature of $37^{\circ} \mathrm{C}$, for $24 \mathrm{~h}$. Then, the clear zones of inhibition were measured [23].

Determining the minimum inhibitory concentration

The Minimum Inhibitory Concentration (MIC) test was conducted using a broth dilution technique as per the ISO standards and the quality assurance guidelines of the World Health Organization (WHO) [23]. The cellfree culture supernatants (CFSs) of lactobacilli strains were serially diluted to two-fold (higher and lower), and were inoculated with the overnight culture of pathogenic bacteria to the final concentration of 107-8 colony-forming unit (CFU/mL) [13]. Also, the absorbance at $600 \mathrm{~nm}$ was measured to determine the MIC level, where the Lactobacillus-free broth was used as a control.

\section{Results}

\section{Isolation and identification of Lactobacillus spp}

Out of 50 different raw cow milk samples, 41 Lactobacillus isolates were obtained, which were later screened and isolated. From the morphology and physiology of the 41 isolates, white and shiny bacterial colonies were observed on the MRS medium. The observed colonies were microscopically gram-positive, non-spore-forming, and non-motile bacteria, also, biochemical properties included catalase-negative and oxidase-negative. Besides, all the Lactobacillus strains showed positive results in carbohydrate fermentation and milk coagulation tests. Further, all the test results were correlated with the Lactobacillus.

According to Figure 3A, the 41 obtained colonies belong to five different Lactobacillus species, viz, L. casei (17 colonies), L plantarum ( 7 colonies), L brevis ( 7 colonies), L acidophilus (6 colonies), and L lactis (4 colonies). These isolated colonies were cultured on the MRS medium with $30 \%$ glycerol and stored at the temperature of $-20^{\circ} \mathrm{C}$. Table 1 reports the morphological characteristics of the five bacterial strains. Also, Table 2 represents the strains' biochemical characteristics resulted from the catalase, oxidase, carbohydrate fermentation, and milk 


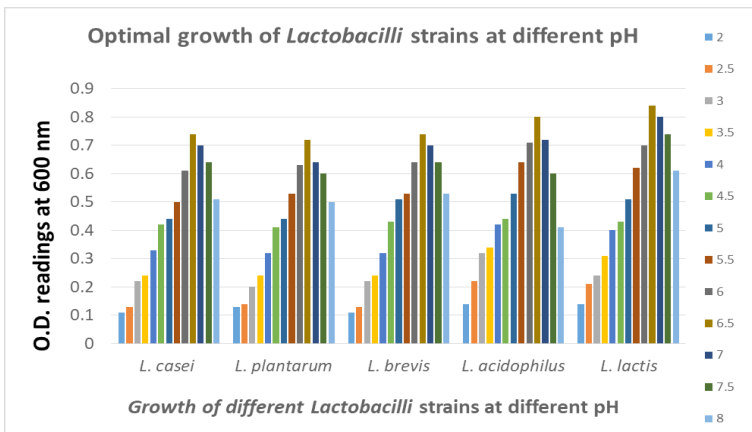

grmm

Figure 1. Determination of $\mathrm{pH}$ for optimal growth in different Lactobacilli strains

For all Lactobacillus strains, the minimal growth was observed at low $\mathrm{pH}$, later, the growth slowly increased to obtain its optimal value, at $\mathrm{pH} 6.5$.

coagulation tests. All these characteristics showed a resemblance to Lactobacillus.

\section{Observation of probiotic potential}

Out of 41 identified Lactobacillus strains (Figure 3A), only 35 Lactobacillus strains showed potential probiotic characteristics. According to Figure 3B, the probiotic colonies include 15 L. casei $(42.85 \%)$, six L. plantarum (17.14\%), six L. brevis (17.14\%), five L. acidophilus (14.28\%), and three L. lactis (8.57\%). However, the rest six isolates did not show potential probiotic characteristics; these isolates included two colonies of $L$. casei, one colony of $L$. plantarum, one colony of $L$. brevis, one colony of $L$. acidophilus, and one colony of $L$. lactis. Hence, out of 41 isolates, 35 colonies of five lactobacilli strains were further assessed for the probiotic potentials.

\section{Determination of $\mathrm{pH}$ for optimal growth}

It is important to determine the survival and growth of Lactobacillus in different $\mathrm{pH}$ conditions that resemble the physiological conditions of the host body, because it can prove the probiotic potential of strains for the host's system [13]. Hence, bacteria need to tolerate the initial acidic stress in the stomach and the other organs of the digestive system, after the administration of the respective food sources. Figure 1 shows the results of the growth of all five Lactobacillus strains at different $\mathrm{pH}$ values ranging from 2.0 to 8.0. Based on the optical density measurements at $600 \mathrm{~nm}$, the minimal growth of bacteria was observed at low $\mathrm{pH}$ values. However, the growth increased with the $\mathrm{pH}$ value and obtained its optimum at a $\mathrm{pH}$ of 6.5 , in all Lactobacillus strains. After $6.5 \mathrm{pH}$ value, there was a moderate growth followed by a slow decline in the growth of Lactobacillus. Thus, all

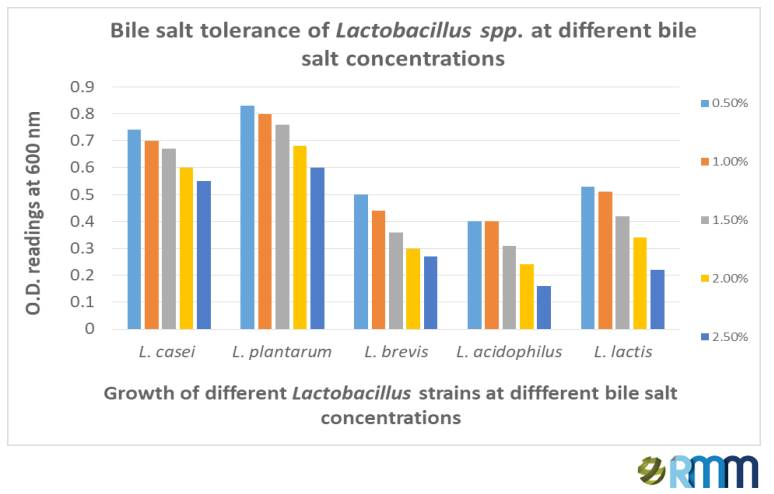

Figure 2. Bile salt tolerance of different Lactobacillus strains for different bile salt concentrations

All Lactobacillus strains showed good growth in different physiological bile concentrations.

Lactobacillus strains showed growth at the $\mathrm{pH}$ range of 2.0 to 8.0. Hence, these growth results show that the bacteria have adapted to grow in acidic and near the neutral $\mathrm{pH}$ conditions.

\section{Tolerance to different bile salt concentrations}

The Lactobacillus strains need to resist against inhibitory substances in the GI tract, like bile salts. Thus, the isolated strains should be assessed to check their probiotic potential. After consumption, raw cow milk endures $0.3 \%$ bile salt concentration [13]. Figure 2 represents the results of bacterial strains that were incubated into five MRS medium tubes containing different bile salt concentrations ranging from $0.5 \%$ to $2.5 \%$. Based on the optical density measurements at $600 \mathrm{~nm}$, the isolated $\mathrm{Lac}$ tobacillus strains showed growth and survival capacity in $0.05 \%$ to $2.5 \%$ of bile salt concentrations.

All Lactobacillus strains showed good tolerance towards the different bile salts concentrations. Besides, all Lactobacillus spp showed good growth at low bile salt concentrations, however, as the bile salt concentrations increased, a decline was observed in growth. Among the five lactobacilli strains, $L$. casei and $L$. plantarum showed good tolerance towards bile salts, compared with L. brevis, L. acidophilus, and L. lactis, which showed a moderate level of tolerance. Hence, results indicated that all Lactobacillus strains have tolerance and resistance to different concentrations of bile salts.

\section{Antibiotic susceptibility test}

All 35 potential probiotics were tested for their antibiotic susceptibility against 16 different antibiotics. Bacteria show remarkable adaptability to develop and transmit antibiotic resistance, which makes susceptibility against 
Table 3. Antibiotic susceptibility test of lactobacillus strains

\begin{tabular}{|c|c|c|c|c|c|}
\hline Antibiotics Used (Conc. in $\mu \mathrm{g}$ ) & L. casei & L. plantarum & L. brevis & L. acidophilus & L. lactis \\
\hline 1. Ampicillin (10) & $\mathrm{R}$ & $\mathrm{R}$ & $\mathrm{R}$ & $\mathrm{R}$ & $\mathrm{R}$ \\
\hline 2. Amoxiclav (5) & s & s & S & s & s \\
\hline 3. Cloxacillin (5) & S & S & S & S & S \\
\hline 4. Azithromycin (15) & $\mathrm{s}$ & $\mathrm{s}$ & $\mathrm{s}$ & $\mathrm{s}$ & $\mathrm{s}$ \\
\hline 5. Cefotaxime (30) & $\mathrm{s}$ & $\mathrm{s}$ & $\mathrm{s}$ & s & $\mathrm{s}$ \\
\hline 6. Cefixime (30) & $\mathrm{s}$ & $\mathrm{s}$ & $\mathrm{s}$ & $\mathrm{s}$ & $\mathrm{s}$ \\
\hline 7. Clindamycin (5) & 1 & 1 & $\mathrm{R}$ & 1 & 1 \\
\hline 8. Cotrimoxazole (25) & S & S & S & s & S \\
\hline 9. Chloramphenicol (30) & 1 & 1 & 1 & 1 & 1 \\
\hline 10. Ciprofloxacin (5) & 1 & 1 & I & 1 & S \\
\hline 11. Ceftriaxone (30) & $\mathrm{s}$ & $\mathrm{s}$ & $\mathrm{s}$ & $\mathrm{s}$ & $\mathrm{s}$ \\
\hline 12. Erythromycin (15) & $\mathrm{s}$ & $\mathrm{s}$ & $\mathrm{s}$ & $\mathrm{s}$ & $\mathrm{s}$ \\
\hline 13. Gentamicin (10) & 1 & 1 & 1 & 1 & 1 \\
\hline 14. Tetracycline (30) & S & S & S & s & S \\
\hline 15. Novobiocin (5) & $\mathrm{s}$ & $\mathrm{s}$ & $\mathrm{s}$ & $\mathrm{s}$ & $\mathrm{s}$ \\
\hline 16. Oxacillin (5) & 1 & 1 & 1 & 1 & 1 \\
\hline
\end{tabular}

antibiotics as a crucial factor for probiotics. Hence, the profile of antibiotic resistance was assessed for all five Lactobacillus strains to evaluate the absence of transferable antibiotic resistance genes in the candidate strains. The results showed that the isolates were sensitive to amoxiclav, cotrimoxazole, erythromycin, tetracycline, cloxacillin, azithromycin, cefotaxime, cefixime, ceftriaxone, and novobiocin. However, some strains showed intermediate resistance against clindamycin, gentamycin, chloramphenicol, and ciprofloxacin. Lastly, a prominent resistance was observed against ampicillin and oxacillin. Table 3 shows the antibiotic resistance profile of the five Lactobacillus spp against 16 antibiotics.

\section{Antimicrobial activity}

A modified agar well diffusion method was used to examine the antimicrobial activity of the selected Lactobacillus strains. The isolates were exposed to pathogenic bacteria, such as S. Typhimurium, S. dysenteriae, E. coli, B. cereus, and H. pylori. Out of the 41 identified Lactobacillus strains, only 35 showed antimicrobial effects. According to Figure 3B, the strains with antimicrobial effects include 15 L. casei (42.85\%), six L. plantarum (17.14\%), six L. brevis (17.14\%), five L. acidophilus (14.28\%), and three L. lactis $(8.57 \%)$. The diameter of the growth inhibition zone recorded for each pathogenic bacterium varied according to bacterial species, because of the varying degrees of antagonism among the Lactobacillus strains and the pathogenic bacteria. The diameter ranged from 12.6 to $17.5 \mathrm{~mm}$. The bacteria were found to have a slightly stronger antagonistic effect against $E$. coli (growth inhibition diameter range, 14.1-17.5 mm) and $B$. cereus (growth inhibition diameter range, 14.4$17.4 \mathrm{~mm}$ ). Table 4 demonstrates the antagonist effects of the five Lactobacillus spp, which can be considered to have probiotic potential.

Each Lactobacillus strain isolated from milk samples was investigated to characterize the release of inhibitory substances, such as bacteriocin, organic acid, and hydrogen peroxide. The pronase $(1 \mathrm{mg} / \mathrm{mL})$ or trypsin $(1$ $\mathrm{mg} / \mathrm{mL}$ ) was treated to the culture supernatants of $L a c$ tobacillus isolates (L. casei, L. plantarum, L. brevis, L. acidophilus, and L. lactis) and the reference strain. The results showed that these treatments do not affect the in- 
Table 4. Antimicrobial properties of lactobacillus strains against pathogens

\begin{tabular}{|c|c|c|c|c|c|}
\hline Lactobacillus Strains & S. Typhimurium & S. dysenteriae & E. coli & B. cereus & H.pylori \\
\hline L. casei & + & + & + & + & + \\
\hline L. plantarum & + & + & + & + & + \\
\hline L. brevis & + & + & + & + & + \\
\hline L. acidophilus & + & + & + & + & - \\
\hline L. lactis & + & + & + & + & - \\
\hline
\end{tabular}

hibitory activities against the indicator strains. This result implies that bacteriocin is not responsible for the inhibitory effects of the tested LAB strains. Also, the catalase treatment on the culture supernatants showed no effect on the inhibitory activities of the Lactobacillus isolates against indicator strains. Hence, the hydrogen peroxide production is not responsible for the inhibitory properties of LAB strains. Moreover, the neutralized supernatant ( $\mathrm{pH}$ 6.5) of each LAB species did not have any inhibitory effect against the indicator strains. Thus, the organic acids production in LAB strains is responsible for their inhibitory effects. Therefore, the isolated Lactobacillus spp were responsible for organic acid production.

Minimal inhibitory concentrations of the cell-free culture supernatants of the isolated Lactobacillus

The selected CFSs of Lactobacillus isolates were used for the MIC assay. The average MIC for the isolated Lactobacillus strains were as follows: $120 \mu \mathrm{L}$ against $S$. Typhimurium; $50 \mu \mathrm{L}$ against $E$. coli; and $100 \mu \mathrm{L}$ against $S$. dysenteriae, B. cereus, and H. pylori. Results showed that the maximum concentrations of the CFSs of Lacto- bacillus strains were required to inhibit the highly pathogenic bacteria, like $S$. dysenteriae, B. cereus, H. pylori, and S. Typhimurium.

A: Identification of LAB species. Among 41 isolated Lactobacillus, 17, 7, 7, 6, and 4 strains belong to $L$. casei, L. plantarum, L. brevis, L. acidophilus, and L. lactis, respectively. B: Among 41 isolated Lactobacillus strains, the antagonistic activity against pathogens was observed in 35 strains, including 15 L. casei, six L. plantarum, six L. brevis, five L. acidophilus, and three L. lactis. C: The growth inhibition zone diameter of different pathogens varies according to the Lactobacillus strain used.

\section{Discussion}

The present study aimed to isolate and characterize the Lactobacillus strains with potential probiotic characteristics from different raw cow milk sources and assess their antimicrobial activities against some pathogenic bacteria. Many researchers provided evidence for the presence of Lactobacillus spp in raw cow milk sources [28]. The pres-
A

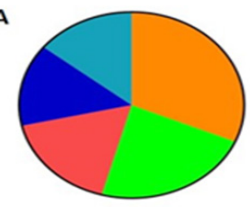

Total $=\mathbf{4 1}$

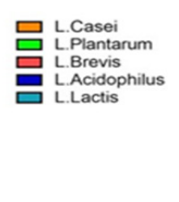

C

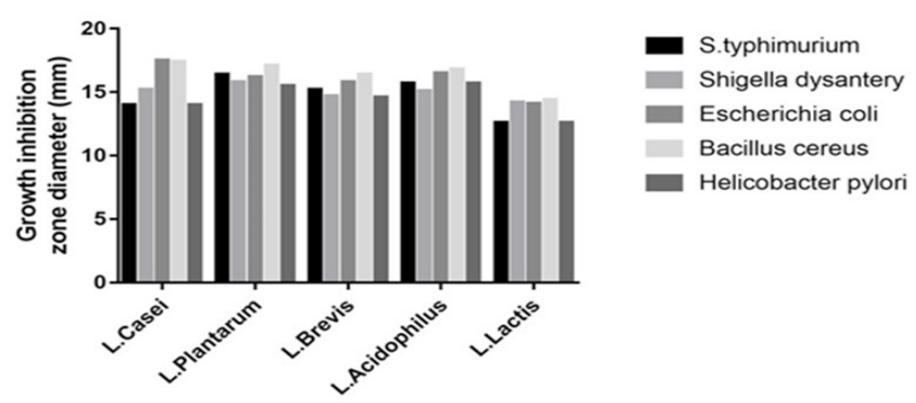

B

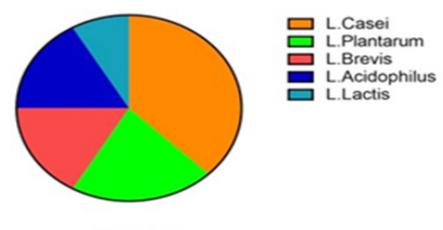

Total $\mathbf{3 5}$

(1) 
ence of Lactobacillus strains has been observed in the primary food source, like milk, which is further processed to make various dairy products. So, this study is mainly focused on assessing the probiotic potential of Lactobacillus strains isolated from raw cow milk sources. Forty-one isolates were obtained from 50 different milk sources and characterized based on their morphology and biochemical characteristics. These isolates were recognized as Lactobacillus, out of which 35 isolates were identified as five different Lactobacillus strains. According to Bergey's manual, they were classified into five different species, such as $L$. casei, L. plantarum, L. brevis, L. acidophilus, and $L$. lactis [20,24]. These 35 Lactobacillus strains were further assessed for their probiotic potentials.

In the biochemical analysis, all 35 isolates of five $\mathrm{Lac}$ tobacillus strains showed negative results for catalase and oxidase tests [29] and positive for carbohydrates fermentation tests. These results show that all five strains of Lactobacillus can ferment carbohydrates, i.e., the strains have the capability of growing in a variety of habitats by utilizing different types of carbohydrates [24].

While evaluating the probiotic potential of Lactobacillus as an effective probiotic, it is important to assess their ability to resist the effects of different $\mathrm{pH}$ conditions and survive in bile conditions. This evaluation is necessary to check the capability of probiotic Lactobacillus to remain viable and active in the host. Strains showing positive growth in such conditions can be considered as potential probiotics [30]. During their transit through the GI tract, the probiotic Lactobacillus strains must survive in the stomach to reach the intestine. In the stomach, the $\mathrm{pH}$ can be as low as 1.5 to 2.0. Also, survival at $\mathrm{pH} 3.0$ can be considered as optimal acid tolerance for assessing the probiotic potential of bacteria [31].

In this research, all Lactobacillus strains showed growth at low $\mathrm{pH}(\mathrm{pH} 2.0$ and 3.0), indicating that the selected Lactobacillus isolates are capable of surviving and growing in the acidic conditions of the stomach [30-34]. Many studies measuring the $\mathrm{pH}$ of GI showed that in the intestine region the $\mathrm{pH}$ value ranges from 6.0 to 7.5 [35-37]. In the present study, Lactobacillus strains survived and grew in this $\mathrm{pH}$ range. Also, optimal growth was observed at $\mathrm{pH} 6.5$, which is near to the $\mathrm{pH}$ value of the small intestine region, which is usually 6.6 [36]. Since the liver daily secrets bile into the small intestine, Lactobacillus strains should tolerate the bile salts to be used as potential probiotics. After consumption, a dairy product endures $0.3 \%$ bile salt concentration [13].

As per Dunne et al. study, the appropriate range of the physiological concentration of human bile is between $0.3 \%$ to $0.5 \%[30,38]$. Hence, this study evaluated the tolerance of Lactobacillus strains to bile salts ranging from $0.5 \%$ to 2.5\%; all Lactobacillus strains showed growth and survival in this range of bile salts concentrations. Also, a decline in growth was observed with increased bile salts concentrations. Hence, the present study indicated the tolerance and resistance of thirty-five Lactobacillus strains to bile salts.

Bacteria show remarkable adaptability to develop and transmit antibiotic resistance [27], which makes susceptibility against antibiotics as a crucial factor for probiotics. Thus, the profile of antibiotic resistance was assessed to ensure the absence of transferable antibiotic resistance genes in the candidate strains. From results, all the strains showed susceptibility to all tested antibiotics except ampicillin and oxacillin, giving them credible safety as probiotic strains. Antimicrobial activity is a vital criterion to establish a probiotic. Lactobacilli elicit their antimicrobial activity by producing substances, like organic acids (lactic, propionic, acetic, succinic acid, etc).

Antimicrobials, such as organic acids and probiotics are being used as food with a safety approach, they can help to reduce pathogenic bacterial loads, in preharvest interventions [39]. Organic acids, such as acetic and lactic acids are usually considered safe [40]. Since the organic acids reduce the $\mathrm{pH}$ of food, they also inhibit other microorganisms' growth (e.g., food pathogen, like $B$. cereus in raw milk); the inhibition of the growth of many foodborne pathogenic microorganisms helps the food to be "safe" for consumption [41, 42]. The antimicrobial activity of organic acids originates from two primary mechanisms: 1) acidifying the cytoplasm, and 2) accumulating free acid anions. Also, organic acids have several advantages to be used as antimicrobial agents; there is no limited acceptable daily intake dosage, they are very cheap and can be manipulated easily, and they slightly change the sensory of the product [43].

Many antibiotics are used in human and animal medicines to treat infections. These utilizations have increased antibiotic resistance. The increase of bacterial antibiotic resistance increases the antibiotic-resistant pathogenic strains and decreases the effectiveness of antibiotics, which has become a reality in the medicinal world. Some broad-spectrum antibiotics disrupt the intestinal microflora and give a chance for opportunistic pathogens to grow $[44,45]$. Hence, researchers have focused on the use of naturally occurring antimicrobials, like organic acids and probiotics, because of the increased concerns on antibiotic-resistant pathogens. The present study showed that Lactobacillus strains can produce organic acid. However, each Lactobacillus strain exerts different 
antimicrobial potential and maybe a part of the immune systems through the microbiome.

Five well-known pathogenic bacteria (S. Typhimurium, $S$. dysenteriae, E. coli, B. cereus, and H. pylori) were used to evaluate the antagonistic activity of isolated LAB strains. These bacteria are responsible for several intestinal and colon diseases in humans $[46,47]$. Helicobacter pylori is a gram-negative bacterium involved in gastric cancer [48]. Also, numerous experimental observations proved that probiotic bacteria potentially protect against the development of colon cancer [48]. Thus, testing the antimicrobial potentials of the isolates on this bacterium could be promising for future cancer investigations.

Amongst the 41 isolated LAB strains, 35 had a relatively similar antagonistic effect on these pathogens. The inhibitory effects against pathogens ( $\%$ of total) were as follows: L. casei (81.82\%), L. plantarum (62.5\%), L. brevis $(66.67 \%)$, L. acidophilus (80\%), and L. lactis (40\%). Hence, this study suggests that $L$. casei and L. acidophilus have more strains with an inhibitory effect against these pathogenic bacteria. Nighswonger et al. demonstrated the probiotic potential of these LAB strains in fermented milk products during refrigerated storage, showing their viability [49]. Also, Osuntoki et al. used fermented dairy products to isolate Lactobacillus spp; they showed antibacterial activity against $E$. coli (diameter: $4.2 \mathrm{~mm}$ ) and S. Typhimurium (diameter: $4.3 \mathrm{~mm}$ ) [50].

The agar well diffusion assays were used to examine the released antimicrobial substances, such as bacteriocin, organic acid, and hydrogen peroxide; the results showed isolates produced organic acids as their inhibitory substances. Lastly, the MIC - a crucial parameter for bacteria to qualify as probiotic - was defined for each strain. The average MIC was $50 \mu \mathrm{L}$ against $E$. coli; $120 \mu \mathrm{L}$ against $S$. Typhimurium; and $100 \mu \mathrm{L}$ against $S$. dysenteriae, B. cere$u s$, and $H$. pylori. Alakomi et al. proved that accumulated lactic acids result in a low $\mathrm{pH}$ environment, also, lactic acid leads to the permeabilization of the outer membrane of gram-negative bacteria and inhibits the urease activity in them [51]. Davoodabadi et al. explored various lactobacilli strains for their effective antimicrobial effects against intestinal infections caused by diarrheagenic E. coli [52]. Moreover, Macfarland found that the risk of antibioticassociated diarrhea in children and adults can be significantly reduced with the help of probiotic lactobacilli [53].

Chen et al. proved that some Lactobacillus strains, like $L$. plantarum can inhibit the adherence of $H$. pylori to human gastric epithelial cells, also, metabolites, like organic acids and proteases along with the $\mathrm{pH}$ factor assist in the antago- nistic activity of CFSs against $H$. pylori [54]. Hence, the present study revealed that the Lactobacillus strains effectively inhibit pathogenic bacteria, such as $S$. Typhimurium, E. coli, B. cereus, S. dysenteriae, and H. pylori.

\section{Conclusions}

Probiotics contain several benefits. They produce the functional end products, such as organic acids that can be utilized by the host. Probiotics also help in preventing diseases by effectively competing with pathogenic bacteria for colonization. Besides, probiotics can increase the level of energy metabolism in the host, impact on human mood and cognitive abilities, and stimulate the host immune system $[11,55]$.

This study isolated the potential probiotic lactobacilli strains from different raw cow milk samples. The probiotic potential assessment showed antimicrobial effects against pathogenic bacteria. Also, the results indicated the survival of Lactobacillus strains in different $\mathrm{pH}$ conditions of the host system and different bile salt conditions. The study also suggests novel Lactobacillus strains as biotherapeutic agents in the formulation of different probiotics. Nonetheless, all tested strains can be susceptible to clinically effective antibiotics, thus, more extensive research is essential to ascertain their efficiency as probiotic bacteria. Moreover, many studies showed that Lactobacillus strains, such as $L$. plantarum shows antifungal properties [56, 57]. Also, gnotobiotic pigs infected with human rotavirus strains showed elevated responses of IFN- $\gamma$ and IL-4 in serum and a decrease in infections when they were fed with food containing L. acidophilus strains [58]. Hence, such Lactobacillus strains can be investigated for their potential antifungal or antiviral properties. Future studies can evaluate these characteristics of probiotic potential in such strains.

\section{Ethical Considerations}

\section{Compliance with ethical guidelines}

All ethical principles are considered in this article. The participants were informed of the purpose of the research and its implementation stages.

\section{Funding}

This research did not receive any grant from funding agencies in the public, commercial, or non-profit sectors.

\section{Conflict of interest}

The author declared no conflict of interest. 


\section{References}

[1] Mohr KI. History of antibiotics research. In: Stadler M, Dersch P, Editors. How to overcome the antibiotic crisis: Facts, challenges, technologies and future perspectives. Cham: Springer International Publishing. 2016; pp. 237-72.

[2] Bechinger B, Gorr SU. Antimicrobial peptides: Mechanisms of action and resistance. J Dent Res. 2017; 96:254-60. [DOI:10.1177/0022034516679973] [PMID] [PMCID]

[3] Munita JM, Arias CA. Mechanisms of antibiotic resistance. In: Kudva IT, Cornick NA, Plummer PJ, Zhang Q, Nicholson TL, et al. Virulence mechanisms of bacterial pathogens, $5^{\text {th }}$ Edition. Am Soc Microbiol. 2016; pp. 481-511. [DOI:10.1128/9781555819286.ch17]

[4] Baharoglu Z, Mazel D. SOS, the formidable strategy of bacteria against aggressions. FEMS Microbiol Rev. 2014; 38:1126-45. [DOI:10.1111/1574-6976.12077] [PMID]

[5] Hotel AC, Cordoba A. Health and nutritional properties of probiotics in food including powder milk with live lactic acid bacteria. Prevention. 2001; 5(1):1-10.

[6] Rashid S, Hassanshahian M. Screening, isolation and identification of lactic acid bacteria from a traditional dairy product of Sabzevar, Iran. Int J Enteric Pathog. 2014; 2(4):e18393. [DOI:10.17795/ijep18393]

[7] Both E, György É, Kibédi-Szabó CZ, Tamás É, Ábrahám B, et al. Acid and bile tolerance, adhesion to epithelial cells of probiotic microorganisms. U P B Sci Bull Series B. 2010; 72(2):37-44. https://www.scientificbulletin.upb.ro/rev_docs arhiva/full2746.pdf

[8] Saarela M, Mogensen G, Fondén R, Mättö J, Mattila-Sandholm T. Probiotic bacteria: Safety, functional and technological properties. J Biotechnol. 2000; 84:197-215. [DOI:10.1016/ S0168-1656(00)00375-8]

[9] Marteau P, Minekus M, Havenaar R, Huis In't Veld JHJ. Survival of lactic acid bacteria in a dynamic model of the stomach and small intestine: Validation and the Effects of Bile. J Dairy Sci. 1997; 80:1031-7. [DOI:10.3168/jds.S00220302(97)76027-2]

[10] Shewale RN, Sawale PD, Khedkar C, Singh A. Selection criteria for probiotics: A review. Int J Probiotics Prebiotics. 2014; 9(1/2):17-22. https://www.researchgate.net/ publication/288067379

[11] Ouwehand AC, Salminen S, Isolauri E. Probiotics: An overview of beneficial effects. In lactic Acid Bacteria: Genet Metab Appl. 2002:279-89. [DOI:10.1007/978-94-017-2029-8_18] [PMID]

[12] Amraii HN, Abtahi H, Jafari P, Mohajerani HR, Fakhroleslam MR, Akbari N. In vitro study of potentially probiotic lactic acid bacteria strains isolated from traditional dairy products. Jundishapur J Microbiol. 2014; 7(6). [DOI:10.5812/ jjm.10168] [PMID] [PMCID]

[13] Prabhurajeshwar C, Chandrakanth K. Evaluation of antimicrobial properties and their substances against pathogenic bacteria in-vitro by probiotic Lactobacilli strains isolated from commercial yoghurt. Clin Nutr Exp. 2019; 23:97-115. [DOI:10.1016/j.yclnex.2018.10.001]
[14] Buzby JC, Roberts T, Lin CT, MacDonald JM. Bacterial foodborne disease: Medical costs and productivity losses. Agric Econ Rep. 1996; 741:1-93. https://www.ers.usda.gov/ webdocs/publications/40722/28371 aer741fm 1 . pdf? $v=4106$

[15] Tebyanian H, Bakhtiari A, Karami A, Kariminik A. Antimicrobial activity of some Lactobacillus species against intestinal pathogenic bacteria. Int Lett Nat Sci. 2017; 65:10-5. [DOI:10.18052/www.scipress.com/ILNS.65.10]

[16] Wang Q, Yamabe K, Narita J, Morishita M, Ohsumi Y, Kusano $\mathrm{K}$, et al. Suppression of growth of putrefactive and food poisoning bacteria by lactic acid fermentation of kitchen waste. Process Biochem. 2001; 37(4):351-7. https:// www.sciencedirect.com/science/article/pii/ $\underline{\text { S0032959201002175 }}$

[17] Yang YJ, Chuang CC, Yang HB, Lu CC, Sheu BS. Lactobacillus acidophilus ameliorates $\mathrm{H}$. pylori-induced gastric inflammation by inactivating the Smad7 and NFkB pathways. BMC Microbiol. 2012; 12(1):38. [DOI:10.1016/S00329592(01)00217-5]

[18] Hartemink R, Domenech VR, Rombouts FM. Lamvab e a new selective medium for the isolation of lactobacilli from faeces. J Microbiol Methods. 1997; 29:77e84. [DOI:10.1016/ S0167-7012(97)00025-0]

[19] Bauer AW, Kirby WMN, Sherries JL. Antibiotics susceptibility testing a standard disc method. Am J Clin Pathol. 1996; 45(4):493-6. https://doi.org/10.1093/ajcp/45.4 ts. 493

[20] Brenner DJ, Staley JT, Krieg NR. Classification of procaryotic organisms and the concept of bacterial speciation. In bergey's manual of systematic bacteriology. Boston, MA: Springer; 2005, .[DOI:10.1007/0-387-28021-9_4]

[21] Hosseinnezhad M, Stenzel DJ, Britz ML. Effect of growth at low $\mathrm{pH}$ on the cell surface properties of a typical strain of Lactobacillus casei group. 2010; 2(3):144-51. https:// www. sid.ir/en/Journal/ViewPaper.aspx?ID=190472

[22] Gilliland SE, Staley TE, Bush LJ. Importance of bile tolerance of Lactobacillus acidophilus used as a dietary adjunct. J Dairy Sci. 1984; 67:3045-3051. [DOI:10.3168/jds.S00220302(84)81670-7]

[23] ISO (International Organization for Standardization). Milk and milk products-determination of the Minimal Inhibitory Concentration (MIC) of antibiotics applicable to bifidobacteria and non-enterococcal Lactic Acid Bacteria (LAB). [Internet] ISO 10932/ IDF 233 standard; 2010. Available From: https://www.iso.org/standard/46434.html

[24] Prabhurajeshwar C, Chandrakanth RK. Probiotic potential of Lactobacilli with antagonistic activity against pathogenic strains: An in vitro validation for the production of inhibitory substances. Biomed J. 2017; 40:270-83. [DOI:10.1016/j. bj.2017.06.008] [PMID] [PMCID]

[25] Mami AZ, Boumehira AR, Hamedi JE, Henni M. Screening of autochthonous Lactobacillus species from Algerian raw goats' milk for the production of bacteriocin-like compounds against Staphylococcus aureus. Afr J Microbiol Res. 2012; 6:2888e98. [DOI:10.5897/AJMR11.1208] 
[26] Toure R, Kheadr E, Lacroix C, Moroni O, Fliss I. Production of antibacterial substances by bifidobacterial isolates from infant stool active against Listeria monocytogenes. J Appl Microbiol, 2003; 95:1058-69. [DOI:10.1046/j.13652672.2003.02085.x] [PMID]

[27] Martinez JL. General principles of antibiotic resistance in bacteria. Drug Discov Today Technol. 2014; 11:33-9. [DOI:10.1016/j.ddtec.2014.02.001] [PMID]

[28] Wassie M, Wassie T. Isolation and Identification of Lactic Acid Bacteria from Raw Cow Milk. Int J Adv Res Biol Sci. 2016; 3(8):44-9. https://ijarbs.com/pdfcopy/ aug2016/ijarbs8.pdf

[29] Pancheniak ED, Soccol CR. Biochemical characterization and identification of probiotic Lactobacillus for swine. Bol do Centro de Pesqui de Processamento de Alimentos. 2005; 23(2):299-310. [DOI:10.5380/cep.v23i2.4485]

[30] Vanniyasingam J, Kapilan R, Vasntharuba S. Isolation and characterization of potential probiotic lactic acid bacteria isolated from cow milk and milk products. AGRIEAST, 2019. 13(1):32-43. [DOI:10.4038/agrieast.v13i1.62]

[31] Azat R, Liu Y, Li W, Kayir A, Lin DB, Zhou WW, et al. Probiotic properties of lactic acid bacteria isolated from traditionally fermented Xinjiang cheese. J Zhejiang Uni-Sci B. 2016; 17(8):597-609. [DOI:10.1631/jzus.B1500250] [PMID] [PMCID]

[32] Sanders ME. Considerations for use of probiotic bacteria to modulate human. Health J Nutr. 2000; 130:3854-905. [DOI:10.1093/jn/130.2.384S] [PMID]

[33] Hiromi K, Masaru N, Miho K, Takashi O, Sadahiro O. Identification and probiotic characteristics of lactococcus strains from plant materials. Japan Agric Res Q. 2004.38 (2):111-117. [DOI:10.6090/jarq.38.111]

[34] Shivram PL, Vishwnath PP. Assessment of probiotic potential of Lactobacillus sp. isolated from cheese and preparation of probiotic ice-cream. Int J Res Ayurveda Pharm, 2012; 3(4):532-36. https://www.researchgate.net/publicaa tion/279541240

[35] Fallingborg J. Intraluminal $\mathrm{pH}$ of the human gastrointestinal tract. Dan Med Bull. 1999; 46(3):183-96.

[36] Evans DF, Pye G, Bramley R, Clark AG, Dyson TJ, Hardcastle JD. Measurement of gastrointestinal $\mathrm{pH}$ profiles in normal ambulant human subjects. Gut. 1988; 29(8):1035-41. [DOI:10.1136/gut.29.8.1035] [PMID] [PMCID]

[37] Fernandez MF, Boris S, Barbes C. Probiotic properties of human Lactobacilli strains to be used in the gastrointestinal tract. J Appl Microbiology. 2003; 94:449-55. [DOI:10.1046/ j.1365-2672.2003.01850.x] [PMID]

[38] Dunne C, O'Mahony L, Murphy L, Thornton G, Morrissey D, O'Halloran S, et al. In vitro selection criteria for probiotic bacteria of human origin: correlation with in vivo findings. Am J Clin Nutr. 2001; 73(2):386s-92s. [DOI:10.1093/ ajcn/73.2.386s] [PMID]

[39] Soon, J, Chadd S, Baines R. Escherichia coli O157: H7 in beef cattle: On farm contamination and pre-slaughter control methods. Anim Health Res Rev. 2011; 12(02):197-211. [DOI:10.1017/S1466252311000132] [PMID]
[40] Hassan M, Kjos M, Nes IF, Diep DB, Lotfipour F. Natural antimicrobial peptides from bacteria: Characteristics and potential applications to fight against antibiotic resistance. J Appl Microbiol. 2012; 113(4):723-36. [DOI:10.1111/j.13652672.2012.05338.x] [PMID]

[41] Palsbøll PJ, Allen J, Berube M, Clapham PJ, Feddersen TP, Hammond PS, et al. Genetic tagging of humpback whales. Nature. 1997; 388(6644):767-9. [DOI:10.1038/42005] [PMID]

[42] SirsatS, Muthaiyan A, RickeS. Antimicrobials for foodborne pathogen reduction in organic and natural poultry production. J Appl Poult Res. 2009; 18(2):379-88. [DOI:10.3382/ japr.2008-00140]

[43] Mani-López E, García HS, López-Malo A. Organic acids as antimicrobials to control Salmonella in meat and poultry products. Food Res Int. 2012; 45(2):713-21. [DOI:10.1016/j. foodres.2011.04.043]

[44] Newell DG, Koopmans M, Verhoef L, Duizer E, AidaraKane A, Sprong H, et al. Food-borne diseases - the challenges of 20 years ago still persist while new ones continue to emerge. Int J Food Microbiol. 2010; 139:S3-15. [DOI:10.1016/j. ijfoodmicro.2010.01.021] [PMID] [PMCID]

[45] Laxminarayan R, Duse A, Wattal C, Zaidi AK, Wertheim $\mathrm{HF}$, Sumpradit N, et al. Antibiotic resistance-the need for global solutions. Lancet Infect Dis. 2013; 13(12):1057-98. [DOI:10.1016/S1473-3099(13)70318-9]

[46] Liu G, Pilla G, Tang CM. Shigella host: Pathogen interactions: Keeping bacteria in the loop. Cell Microbiol. 2019; 28:e13062. [DOI:10.1111/cmi.13062]

[47] Li H, Xu CX, Gong RJ, Chi JS, Liu P, Liu XM. How does Helicobacter pylori cause gastric cancer through connexins: An opinion review. World J Gastroenterol. 2019; 25(35):5220. [DOI:10.3748/wjg.v25.i355220] [PMID] [PMCID]

[48] Guarner F, Khan AG, Garisch J, Eliakim R, Gangl A, Thomson A, et al. World gastroenterology organisation global guidelines: Probiotics and prebiotics. J Clin Gastroenterol. 2012; 46(6):468-81. https://www.worldgastroenterology. org/guidelines/global-guidelines/probiotics-and-prebiotics/probiotics-and-prebiotics-english

[49] Nighswonger BD, Brashears MM, Gilliland SE. Viability of lactobacillus acidophilus and lactobacillus casei in fermented milk products during refrigerated storage. J Dairy Sci. 1996; 79:212-9. [DOI:10.3168/jds.S0022-0302(96)76353-1]

[50] Osuntoki AA, Ejide OR, Omonigbehin EA. Antagonistic effects on enteropathogenic and plasmid analysis of Lactobacilli isolated from fermented dairy products. Biotechnol 2008; 7:311e6. [DOI:10.3923/biotech.2008.311.316]

[51] Alakomi HL, Skyttä E, Saarela M, Mattila-Sandholm T, Latva-Kala K, Helander IM. Lactic acid permeabilizes gram-negative bacteria by disrupting the outer membrane. Appl Environ Microbiol. 2000; 66(5):2001-5. [DOI:10.1128/ AEM.66.5.2001-2005.2000] [PMID] [PMCID]

[52] Davoodabadi A, Soltan Dallal MM, Lashani E, Tajabadi Ebrahimi M. Antimicrobial activity of lactobacillus spp. isolated from fecal Flora of healthy breast-fed infants against diarrheagenic escherichia coli. Jundishapur J Microbiol. 2015; 8(12):e27852. [DOI:10.5812/jjm.27852]

[53] McFarland LV. Probiotics and diarrhea. Ann Nutr Metab. 2010; 57(Suppl):10-11. [DOI:10.1159/000309016] [PMID] 
[54] Chen X, Liu XM, Tian F, Zhang Q, Zhang HP, Zhang H, et al. Antagonistic activities of lactobacilli against Helicobacter pylori growth and infection in human gastric epithelial cells.J Food Sci. 2012; 77(1):M9-14. https://doi.org/10.1111/ j.1750-3841.2011.02498.x

[55] Rijkers GT, Bengmark S, Enck P, Haller D, Herz U, Kalliomaki $\mathrm{M}$, et al. Guidance for substantiating the evidence for beneficial effects of probiotics: Current status and recommendations for future research. J Nutr Biochem. 2010; 140(3):671S-6S. https://academic.oup.com/jn/ article/140/3/671S/4600443

[56] Rizzello CG, Cassone A, Coda R, Gobbetti M. Antifungal activity of sourdough fermented wheat germ used as an ingredient for bread making. Food Chem. 2011; 127(3):952-9. [DOI:10.1016/j.foodchem.2011.01.063] [PMID]

[57] Delavenne E, Mounier J, Déniel F, Barbier G, Le Blay G. Biodiversity of antifungal lactic acid bacteria isolated from raw milk samples from cow, ewe and goat over one-year period. Int J Food Microbiol. 2012; 155(3):185-90.[DOI:10.1016/j.ijj foodmicro.2012.02.003] [PMID]

[58] Wen K, Azevedo MS, Gonzalez A, Zhang W, Saif LJ, Li G, et al. Toll-like receptor and innate cytokine responses induced by lactobacilli colonization and human rotavirus infection in gnotobiotic pigs. Vet Immunol Immunopathol. 2009; 127(3-4):30415. [DOI:10.1016/j.vetimm.2008.10.322] [PMID] [PMCID] 